\title{
Evaluation of Atmospheric and Aqueous Corrosion of Passenger Car Body in Mosul City through the Year 2009-2010
}

\author{
R. J. Al - Ghadanfary G. M. Hannoush \\ Lecturer \\ Ass. Lecturer \\ Technical Institute / Mosul
}
H. A. Al-kareem
Engineer

\begin{abstract}
Corrosion of five steel bodies of passenger cars of models 1985, 1990, 1995, 2000, \& 2005 that are used in Mosul city were studied under atmospheric and aqueous during 2009-2010. Atmospheric corrosion rates were below $1.7 \mathrm{mpy}$, which is classified as low corrosion, this is due to dry weather conditions during the study period, and the quality of steels of the car bodies. Aqueous corrosion rates were also low, below $4.57 \mathrm{mpy}$, and this is due to good water quality of Mosul, low Langelier saturation index, ideal corrosion index, and the quality of steel body cars.
\end{abstract}

Key Words: Mosul city, Atmospheric Corrosion, Car Body Steels, 2010.

$$
\begin{aligned}
& \text { حساب التآكل الجوي والتآكل الرطب لأبدان سيارات الركاب في مدينة الموصل خلا } \\
& \text { 2010 - } 2009 \\
& \text { حسنين عبدالكريم إبراهيم }
\end{aligned}
$$

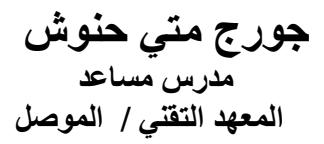

$$
\begin{aligned}
& \text { رائق جمال الغضنفري } \\
& \text { مدرس }
\end{aligned}
$$

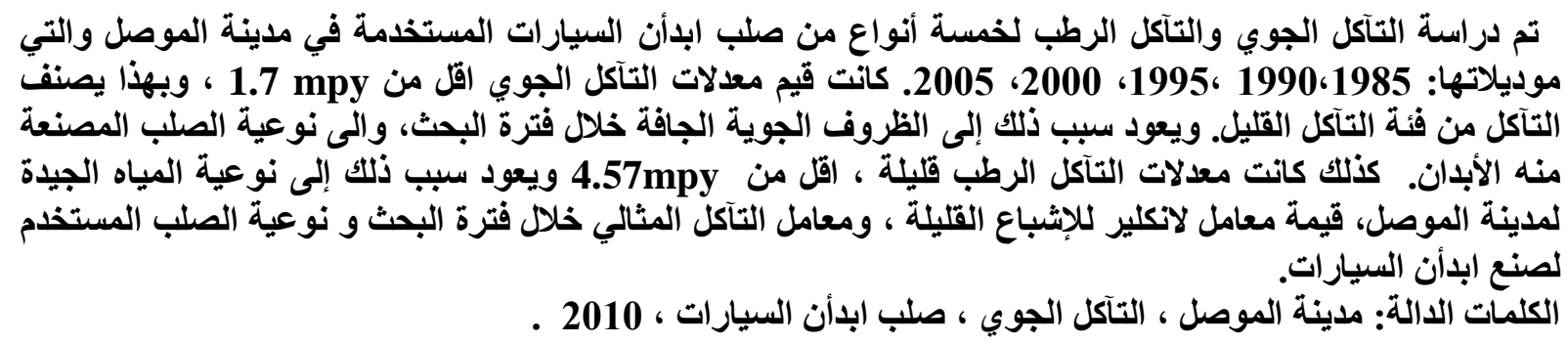

Received: 18 - 12 - 2012

Accepted: 30 - 6 - 201 


\section{Introduction}

Automotive industry has become one of the key sectors of the economy throughout the world. More than $16 \%$ of working population are employed in activities related to the automotive sector in industrial countries [1].After 1973 and 1979 oil crisis, strategies to improve manufacturing costs, and improve profit margin, has brought about considerable change in automotive industry. New designs, improved processing, and new and/or improved materials and components have been developed to meet the challenge of optimum energy/strength/weight ratios. This is well understood by constant struggle to develop cars with high passive safety without increasing fuel consumption. High passive safety requires a very stiff behavior of the crash components. Accomplishing this often leads to an increase in the weight of the components. An increase in weight results in higher fuel consumption which is injurious for the environment as well as or car owner economy [2]. Also, continuous improvements in corrosion resistance field, had led to extended warranties which are currently 6-10 years for perforation, and 1-5 year for cosmic corrosion [3].

The severity of extended corrosion varies considerably throughout the world due to differences in the chemistry of the environment. Maximum corrosion always occurs in snow belt areas due to de-icing salts, and along coastal areas where warm humid salts atmosphere exists. During $21^{\text {st }}$ century the chemistry of the environment changed dramatically. As a result of the changes, atmospheric corrosion of the cars increased; so, the current car users are facing a major problem which is corrosion that affects almost all parts of the car body [4].

Corrosion, is usually defined as deteriorative caused by chemical or electrical reaction with its environment [5]. So, car body corrosion is a result of electricity flow from not-well oxygenated areas that will act as a negative electrode, to another well supplied oxygen area, which will act as a positive electrode, in the presence of an electrolyte. Disobliging car design consideration is probably the main cause for body corrosion, due to sale potential, designing attractive shapes, and accountants monitor costs to meet price competitions [6]. Car bodies normally suffer from general and crevice corrosion. Corrosion rates depend upon both: metal alloy properties, and the environment variables which are; $\mathrm{pH}$ acidity, oxidizing power, temperature and heat transfer, fluid movement, and concentration of solvent components. Alloy steels are among the commonly used materials in sheet metal forming technology for car bodies. They are grouped, from European point of view into: temper rolled steels, microalloyed steels, re-phosphorised steels, dual-phased steels, bake-hardening steels, high strength steels, and isotropic steels [7].

Langan et al [8], studied three high strength low alloy steels in long-term exposure under constant immersion in an aqueous 3.5\% sodium chloride solution to evaluate corrosion rates. It was concluded that variation in weight loss between the three coupons tested for each alloy was greater than differences between the alloys. The corrosion due to exposure to saline environment does not appear to be critical factor in alloy selection. Hamzah [4], studied the corrosion behavior and performance between coated and uncoated steel sheets, which are used in car body manufacturing. It was concluded that micro-scratches are responsible for crevice corrosion by allowing moisture diffusion through it, forming blisters that will enlarge by excessive moisture continuing to build under paint coating. Diaz et al [9], studied the mechanism of rust layer formation on unpainted weathering steels of car bodies under atmospheric corrosion conditions. Their study revealed that the most important factors are: time of wetness( TOW ), wet/dry cycling, and the presence of species, such as $\mathrm{SO} 2$ and $\mathrm{Cl}^{-}$. Garcia et al [10], studied mill annealed AISI 4130 steel at $400 C^{\circ}$ for $1,1.5,2$ hour periods. It 
was concluded that mill-annealing conditions are favorable to improve toughness of steel. Katundi et al [11], concluded from their studies on corrosion behavior of welded steel sheets that were used in car industry, that pitting corrosion damage and crack initiation, always began and initiate at the heat affected zone HAZ, in the welded steel sheets.

The present study will focus on atmospheric as well as aqueous corrosion in car body of five European passenger cars of models 1985-2005, during the year 2009-2010, due to that major of Mosul city cars are of model lower than 2005. The general corrosion of car body is due to warm humid atmosphere and time of wetness, as well as car scrapping because of accidents obsolenscence, and corrosion correlation between injury in car accidents and car age.

\section{Practical Part :}

Five samples, from roofs of European passenger cars that were used in Mosul City, of models 1985 - 2005, were been cut, by electrical hand grinder. From these samples, atmospheric coupons were been cut to the size $100 * 150 \mathrm{~mm}$, according to ASTM G-50, while aqueous coupons were been cut into the size $25 * 50 \mathrm{~mm}$, according to ASTM G-31 The tensile samples were of $10 \mathrm{~mm}$ wide and of gauge length $50 \mathrm{~mm}$, according to DIN 50145 . The following procedure was applied at samples to remove paint from their surfaces, and preparing them for tests: immersing in $10 \% \mathrm{HCl}$, then immersing in $5 \% \mathrm{NaOH}$, then cleaned with distilled water, rinsed and dried with warm air. The samples were wet ground to 600 emery paper by Metasrev electric grinder, then cleaned by distilled water, dried by hot air, and finally stored in dessecator.

Atmospheric corrosion coupons were set outdoors, inclined 45 degrees to the horizon, and directed to the West. They were removed each month for weight loss test [1]. Aqueous corrosion coupons were drilled to $1 \mathrm{~mm}$ hole at the upper side, suspended in 1 liter tap water. Their weight loss was measured weekly [1].

The procedure applied for removing corrosion constituents from the coupon surface was: placing the coupons in turbulent solution of diluted $\mathrm{HCl}$, heated to 40 degrees centigrade, for 10 minutes, then immersing in $(50 \mathrm{gm} \mathrm{NaOH}+200 \mathrm{gm}$ granulated Zinc $)$, then cleaning with distilled water, then drying by warm air, and weighing with digital balance with $0.01 \mathrm{gm}$ accuracy.

Tensile tests were carried out on Tokyo Kikoyo universal tensile testing machine, while sheet thicknesses were measured by $0.01 \mathrm{~mm}$ accuracy digital vernier, and the results were transferred to American Sheet Gage Number. Vickers hardness tests were carried on Wolpert Micro-Hardness tester. Samples from car sheets were mounted using automatic Metaserv specimen mounting. The specimens were then ground, polished, etched by $2 \%$ Nital then $4 \%$ Picral, and microscopically examined, while macro-structures were examined Zeiss stereomicroscope.

\section{Results and Discussion :}

Table1, shows the mechanical properties of sheet car steels, as resulted from tensile and micro-hardness tests, while table 2 shows their chemical composition obtained by analyzing the samples by SDI Brucker Alloy Analyzer. Table 3, shows Mosul city weather activities during 2009-2010, Table 4, give the results of atmospheric corrosion rates in mils per year monthly, at for aqueous corrosion weekly. while table 5, reveals physical and chemical 
composition of fresh water during the period of aqueous corrosion test . Table 6, shows Langlier Saturation Index (LSI) and corrosion power equation calculated for each car tested.

\section{Atmospheric Corrosion:}

Weather characteristics have direct influence on atmospheric corrosion effects, including aggressiveness impact of the pollution agents throughout period of this study [14, 16]. Table 3, gives weather activities of Mosul City during Oct. 2009 - May 2010. From this table, it can be concluded that time of wetness occurred during Dec., Jan., \& Feb.[1], while maximum rain fall occurred during Dec. 2009. Solid particle concentration above average $125 \mathrm{mg} / \mathrm{m}^{3}$ [14],occurred during Oct., Nov., Dec., Apr., \&May. From plate1 (a-e) which represents micro-structures of the studied car body steel.. Micro-structures are pearlite and ferrite, they differ in grain size and cold work ratio ( Tables $1 \& 2$ ).

Table 1 : Mechanical Properties and Sheet Thicknesses of the Selected Cars

\begin{tabular}{|c|c|c|c|c|c|}
\hline Car Sample N & Car Sample Mode & Sheet Gage N & HV & $\boldsymbol{\sigma}_{\text {u, Nlmm }}$ & Elong\% \\
\hline 1 & Car Model 1985 & 22 & 124 & $\mathbf{3 7 2}$ & $\mathbf{2 7 . 6}$ \\
\hline 2 & Car Model 1990 & 19 & 108 & $\mathbf{3 4 9}$ & $\mathbf{3 2 . 1}$ \\
\hline 3 & Car Model 1995 & $\mathbf{2 0}$ & 137 & $\mathbf{4 3 8}$ & $\mathbf{2 5 . 5}$ \\
\hline 4 & Car Model 2000 & 22 & 122 & 383 & 30.4 \\
\hline 5 & Car Model 2005 & 19 & 148 & 473 & $\mathbf{2 2 . 8}$ \\
\hline
\end{tabular}

Table 2: Chemical Composition of Selected Body Sheet Cars Material ( Analyzed by SDI Brucker Alloy Analyzer)

\begin{tabular}{|c|c|c|c|c|c|c|}
\hline Car Sample \& Model & $\mathrm{C} \%$ & Si\% & Mn\% & $\mathbf{P \%}$ & $\mathbf{S \%}$ & Others\% \\
\hline Sample1 Model1985 & 0.13 & 0.19 & 1.0 & 0.04 & 0.9 & Fe balance \\
\hline Sample 2 Model 1990 & 0.09 & 0.49 & 0.09 & 0.06 & $\mathbf{0 . 0 3}$ & $\begin{array}{c}\text { Al 0.05, Nb 0.03, Cu 0.35, Cr } 0.22 \\
\text {-Fe balance }\end{array}$ \\
\hline Sample 3 Model 1995 & 0.04 & 0.09 & 0.2 & 0.004 & 0.01 & $\begin{array}{c}\text { Al0.04, Ni0.03,Cu0.13, Fe } \\
\text { balance }\end{array}$ \\
\hline Sample 4 Model 2000 & $\mathbf{0 . 0 9}$ & 0.3 & 1.6 & - & - & Nb0.04, V0.03, Mo0.3, Fe balance \\
\hline $\begin{array}{ll}\text { Sample5 } & \text { M0del } 2005\end{array}$ & 0.07 & - & 2.0 & 0.08 & $\mathbf{0 . 0 3}$ & Al0.02,Ti0.05, Fe balance \\
\hline
\end{tabular}

Table 3: Atmospheric Activities of Mosul City Weather during 2009-2010 [12]

\begin{tabular}{|c|c|c|c|c|c|c|c|c|}
\hline Weather Activity & $\begin{array}{l}\text { Oct } \\
2009\end{array}$ & $\begin{array}{l}\text { Nov } \\
2009\end{array}$ & $\begin{array}{l}\text { Dec } \\
2009\end{array}$ & $\begin{array}{l}\text { Jan } \\
2010\end{array}$ & $\begin{array}{l}\text { Feb } \\
2010\end{array}$ & $\begin{array}{l}\text { March } \\
2010\end{array}$ & $\begin{array}{l}\text { Apr } \\
2010\end{array}$ & $\begin{array}{l}\text { May } \\
2010\end{array}$ \\
\hline Av. Max Temp, ${ }^{\circ} \mathrm{C}$ & 32.5 & 20.4 & 16 & 14.3 & 17.5 & 19.7 & 25.8 & 34.2 \\
\hline Av. Min Temp, ${ }^{0}$ C & 15 & 9.3 & 7.0 & -0.1 & 5.6 & 8.5 & 11.7 & 18.2 \\
\hline Av. Relative Humidity\% & 46 & 66 & 80 & 80 & 74 & 68 & 62 & 44 \\
\hline Rain Fall, mm & 13.3 & 28.3 & 92 & 0.01 & 24.9 & 28.1 & 35.7 & 1.5 \\
\hline Atmos. Pressure NImm ${ }^{2}$ & 101.4 & $\mathbf{1 0 1 . 8}$ & 101.88 & 100.25 & 101.3 & $\begin{array}{l}101.47 \\
\end{array}$ & 101.21 & 100.94 \\
\hline Solid Particle Concentration, mg & 338 & 235 & 143 & Nil & Nil & Nil & 599 & 307 \\
\hline Av. Dust Fall, g/m2 & 19 & 9 & 13 & - & 27 & 29 & 85 & $\mathbf{0}$ \\
\hline
\end{tabular}


Fig.1, shows corrosion rate of car body steels during 2009-2010, in Mosul City. It can be seen that the relationships are fitted to a power model that is described $[15,17,20]$ by the expression:

$\mathbf{C}=\mathbf{A} \mathbf{t}^{\mathbf{n}}$

Where $\mathrm{C}$ is the corrosion after time, $\mathrm{t}$, while, $\mathrm{n}$ and $\mathrm{A}$ are constants. The value of $\mathrm{n}$ gives a measure for the resistance to transport processes within the corrosion product oxide once it is formed. When $\mathrm{n}=0.5$, an ideal diffusion controlled mechanism case is formed, i.e. all corrosion products remain on the metal surface.

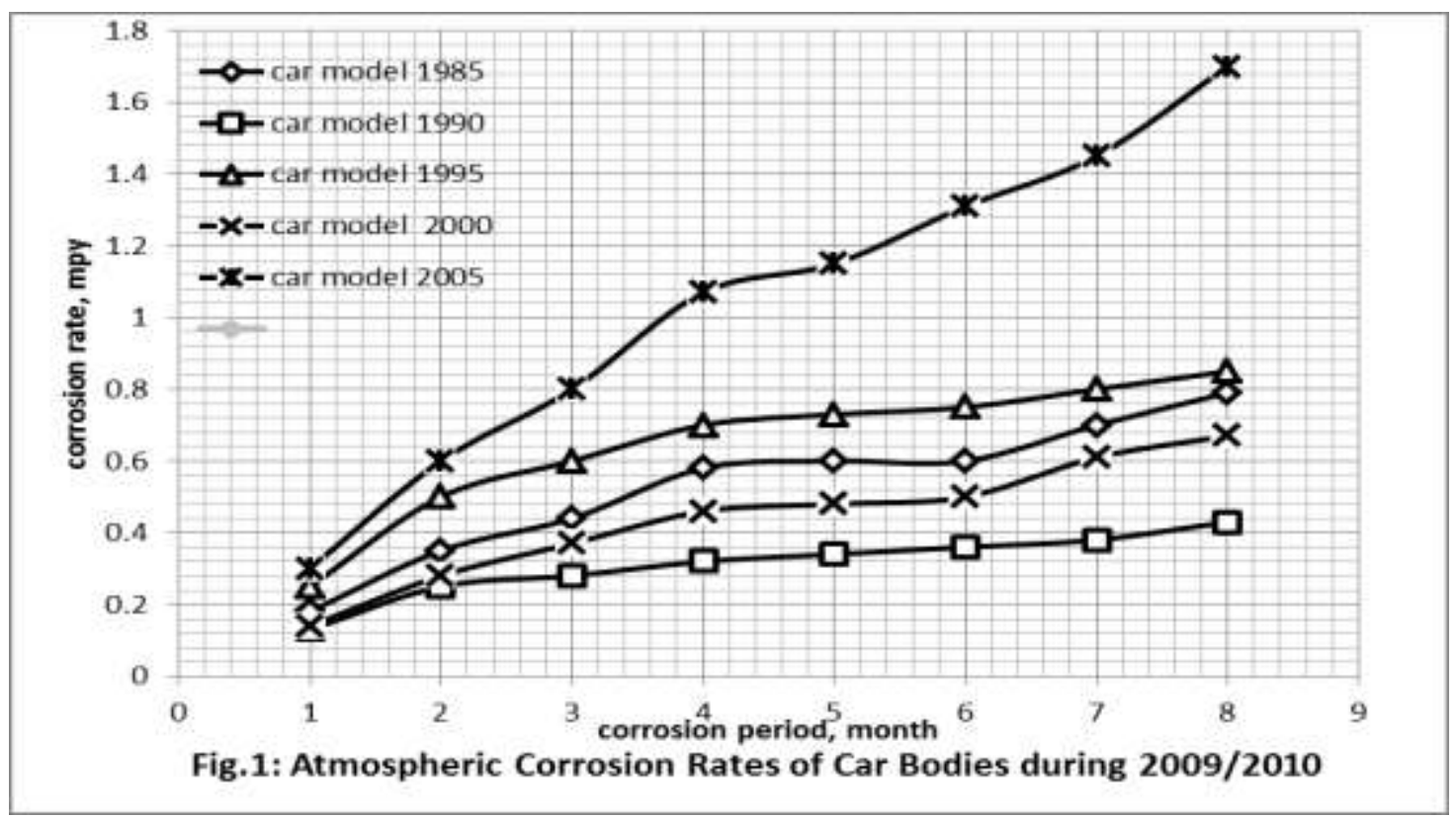

When $\mathrm{n}$ is increased, diffusion process is accelerated as a result of rust detachment either by erosion flaking or cracking. Hence, from fig. 1 and table 4,

Table 4: Results of Atmospheric and Aqueous Corrosion Tests on Car Body Steels in Mosul City during 2009/2010

\begin{tabular}{|c|c|c|c|c|c|c|c|c|c|c|c|c|c|}
\hline \multirow{2}{*}{$\begin{array}{l}\text { Car } \\
\text { Model }\end{array}$} & \multirow{2}{*}{$\begin{array}{l}\text { Corrosion } \\
\text { Index, } n\end{array}$} & \multicolumn{8}{|c|}{$\begin{array}{l}\text { Atmospheric Corrosion Rates, } \\
\text { mpy* / month }\end{array}$} & \multicolumn{4}{|c|}{$\begin{array}{l}\text { Aqueous Corrosion } \\
\text { Rates, mpy* per week }\end{array}$} \\
\hline & & 1 & 2 & 3 & 4 & 5 & 6 & 7 & 8 & 2 & 4 & 6 & 8 \\
\hline 1985 & 0.66 & 18 & 0.35 & 0.44 & 0.58 & 0.6 & 0.6 & 0.7 & $\mathbf{0 . 7 9}$ & 0.85 & 1.23 & 1.63 & 1.7 \\
\hline 1990 & $\mathbf{0 . 5 3}$ & $\mathbf{0 . 1 3}$ & 0.25 & 0.28 & $\mathbf{0 . 3 2}$ & 0.34 & 0.36 & $\mathbf{0 . 3 8}$ & $\mathbf{0 . 4 3}$ & 0.61 & 0.92 & 1.2 & 1.45 \\
\hline 1995 & 0.74 & 0.25 & 0.5 & 0.6 & 0.7 & 0.73 & 0.75 & 0.8 & 0.85 & 1.86 & 2.0 & 2.21 & 2.8 \\
\hline 2000 & 0.63 & 0.14 & 0.28 & $\mathbf{0 . 3 7}$ & 0.46 & 0.48 & 0.5 & 0.61 & 0.67 & 0.92 & 1.2 & 1.38 & 1.55 \\
\hline 2005 & 0.79 & 0.3 & 0.6 & 0.8 & 1.07 & 1.15 & 1.31 & 1.45 & 1.7 & 2.45 & 3.08 & 3.89 & 4.22 \\
\hline
\end{tabular}




\section{*mils per year}

car body steels can be arranged according to their corrosion resistance ascendentaly, car model 1990, car model 2000, car model 1985, car model 1995, and car model 2005. Also, atmospheric corrosion rate can be classified as very low for all car models studied except for car model 2005 which can be classified as low corrosion rate [15,17]. Low corrosion rates can be well understood by atmospheric corrosion mechanism. Corrosion is initiated by forming an oxide film on the steel surface in low humidity periods ( October and November -2009 , Table 3 ). This oxide film may dissolve due to high humidity, or break due to rainfall ( November, December - 2009, January, February, March, and April - 2010, Table 3). This dissolution of the oxide film may cause local breakage and enhance corrosion, plate $1 \& 2$ [18, 19].
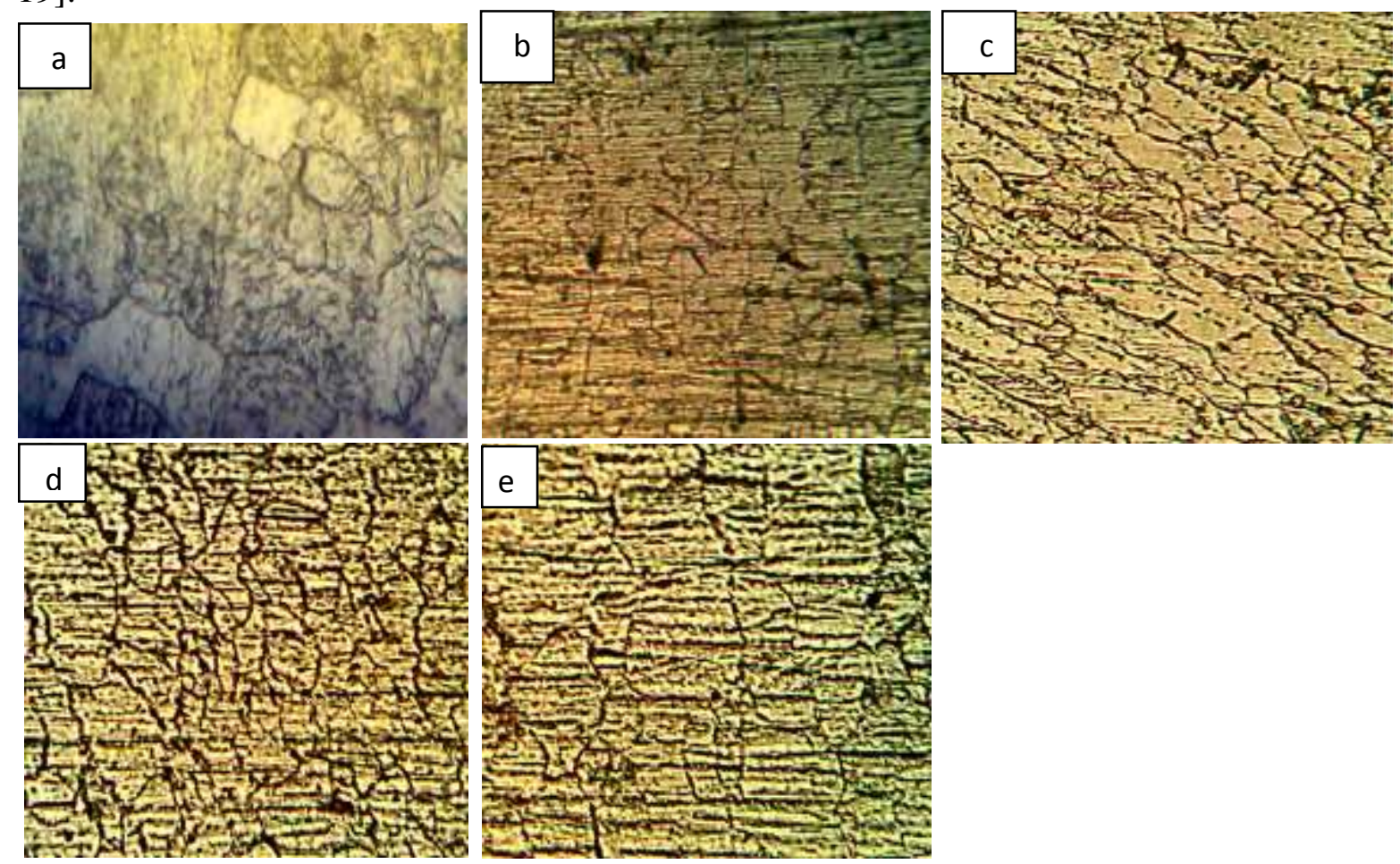

Plate 1: Micro-Structures of Body Cars, a- car model 1985, b- car model 1990, c- car model 1995, d- car model 2000, e- car model 2005.Structure: Ferrite (light area ) +Pearlite (dark area) Etchant: $2 \%$ Nita Magnification: X600
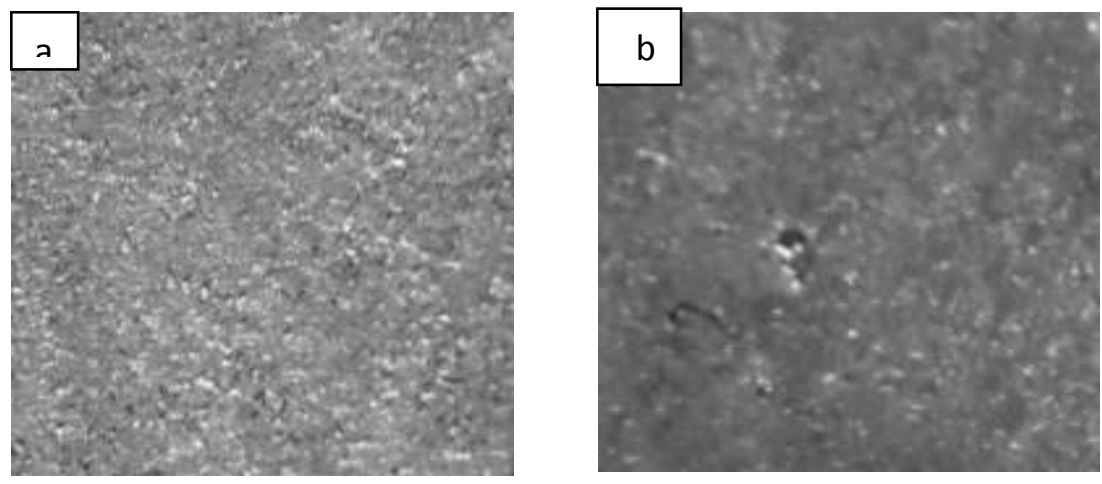

Plate 2: Atmospheric Corrosion of car model 2005 surface specimen a- after 4 months b- after 8 months Magnification : X40 
For comparison, and according to ISO 9223 corrosivity categories classification, the table blow shows corrosivity categories in five Eurapean cities during the year 2000-2001[20] , as well as that of Mosul city during the year 2009-2010.

\begin{tabular}{|l|l|l|l|l|l|l|}
\hline City & Paris & London & Moskow & Rome & Madrid & Mosul \\
\hline $\begin{array}{l}\text { corrosivity categories* } \\
\text { C1 } 1.3 \text { (very low) } \\
\text { C2 1.3 }-25 \text { (low) }\end{array}$ & C2(9.93) & C2(11.8) & C2(9.4) & C2(5.5) & C2(5.3) & $\begin{array}{c}\text { C1** } \\
\text { (refer to table 5) }\end{array}$ \\
\hline
\end{tabular}

* $\mathrm{C} 2$ - low corrosion rate

**all cars tested are of C1 corrosivity category except car model 2005 which is of C2.

Low corrosion rates of car body steels in Mosul, compared with that of European cities, may be well explained, by lower duration of time of wetness( TOW ), and moderate presence of $\mathrm{SO}_{2}$ which assists the formation of the protective layer on car body steels.

\section{Aqeuous Corrosion:}

Water aggressiveness is usually affected by: amount of dissolved Oxygen, type and amount of salts ingredients, $\mathrm{pH}$ of water, temperature and water flow rate, organic and microorganisms, and content of solid particles. The previous factors are controlled by Langelier Saturation Index (LSI) [21] :

Corrosion Rate $($ CR in $\mathrm{mdd})=\mathbf{- 1 2 . 5}(\mathrm{LSI})+\mathbf{8 . 9 9} \quad($ mdd $=$ milli-decimeter per day)

For Mosul City fresh water, Langelier saturation index is less than (-3) as seen from table 6, i.e. low corrosion rates are expected for all sheet steel studied [21]. Also, water quality index WQI, for Mosul city fresh water during the period of the research is computed to be 2.985 36.99, which is classified as good water [24]. From table 5, water hardness is over $150 \mathrm{mg} / \mathrm{L}$, i.e. corrosion rates are decreased by water hardness increase [23].

Table 5: Physical and Chemical Composition of Freshwater 2010 [12]

\begin{tabular}{|c|c|c|c|}
\hline Freshwater Property & April 2010 & May 2010 & June 2010 \\
\hline Water Quality Index [23] & 36.99 & 33.58 & 29.85 \\
\hline Av. Water Temperature ${ }^{\circ} \mathrm{C}$ & 18 & 27 & 30.8 \\
\hline Turbidity, mg/L & 2.64 & 3.76 & 3.32 \\
\hline Total Hardness, mg/L & 227 & 201 & 190 \\
\hline Alkalinity, mg/L & 148 & 142 & 137 \\
\hline pH & 7.71 & 7.73 & 7.7 \\
\hline Electrical Conductivity, $\mu \mathrm{s} / \mathrm{cm}$ & 448 & 398 & 387 \\
\hline Total Dissolved Particles, mg/L & 291 & 272 & 243 \\
\hline Calcium, mg/L & 49 & 42 & 41 \\
\hline Chlorides, mg/L & 27 & 26 & 24 \\
\hline Magnesium, mg/L & 18 & 15 & 17 \\
\hline Nitrogen Dioxide, mg/L & 0.002 & 0.002 & 0.001 \\
\hline
\end{tabular}

The power model equation, $\mathbf{C}=\mathbf{A} \mathbf{t}^{\mathbf{n}}$, calculated for car models aqueous corrosion rates, yielded that the index $\mathbf{n}$, varied between $0.4-0.66$ (table 6 ), 
Table 6: Results of Aqueous Corrosion Tests on Car Body Steels in Mosul City During 2010

\begin{tabular}{|c|c|c|c|c|c|c|c|}
\hline \multirow{2}{*}{$\begin{array}{l}\text { Car } \\
\text { Mod } \\
\text { e }\end{array}$} & \multicolumn{5}{|c|}{$\begin{array}{c}\text { Aqueous Corrosion Rates, mpy } \\
\text { per week }\end{array}$} & \multirow{2}{*}{$\begin{array}{c}\text { Langlier Saturation } \\
\text { Index } \\
\text { LSI }\end{array}$} & \multirow{2}{*}{$\begin{array}{c}\text { Corrosion } \\
\text { Power Eq. } \\
\mathbf{C}=\mathbf{A t}^{\mathbf{n}}\end{array}$} \\
\hline & 2 & 4 & 6 & 8 & 10 & & \\
\hline 1985 & 0.85 & 1.23 & 1.63 & 1.7 & 1.84 & -0.102 & $\mathrm{C}=0.62 \mathrm{t}^{0.49}$ \\
\hline 1990 & 0.61 & 0.92 & 1.2 & 1.45 & 1.6 & -0.028 & $C=2.6 t^{0.66}$ \\
\hline 1995 & 1.86 & 2.0 & 2.21 & 2.8 & 3.68 & -0.0872 & $\mathrm{C}=1.28 \mathrm{t}^{0.38}$ \\
\hline 2000 & 0.92 & 1.2 & 1.38 & 1.55 & 1.9 & - 0.076 & $\mathrm{C}=2.45 \mathrm{t}^{0.64}$ \\
\hline 2005 & 2.45 & 3.08 & 3.89 & 4.22 & 4.57 & - 0.1256 & $\mathrm{C}=1.8 \mathrm{t}^{0.4}$ \\
\hline
\end{tabular}

which emphasizes ideal corrosion conditions, which means that the rust layer on steel is formed due to interaction with fresh water ingredients and physiochemical behavior of the corroded layer[23]. The value of the parameter A (table 6), provides a criterion for gauging short-time susceptibility. It provides a measure for the internal reactivity of steel surface as reflected in its tendency for that surface for producing a corrosion product layer in short time exposure [22]. Car model 1990 has lower corrosion rate, while car model 2005 has the largest corrosion rate, fig. 2 .

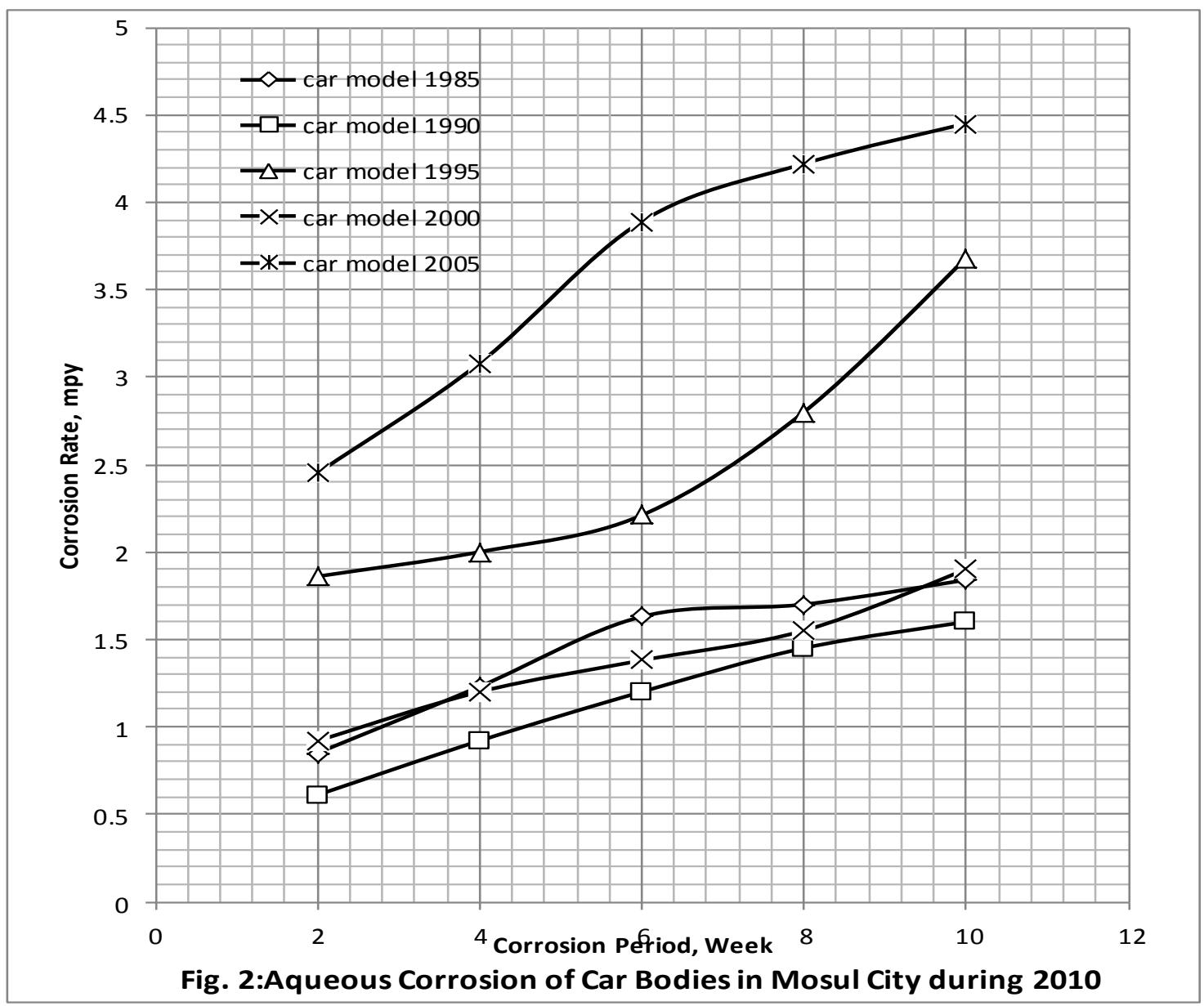


This can be explained by higher percentages of micro-alloying elements ( $\mathrm{Si}, \mathrm{Cu}, \& \mathrm{Cr}$ ) which raise corrosion resistance of steels, or the thermo-mechanical processing of the steel, and the final mechanical properties of the steels, Table1\&2, Plate $1 \& 3$.
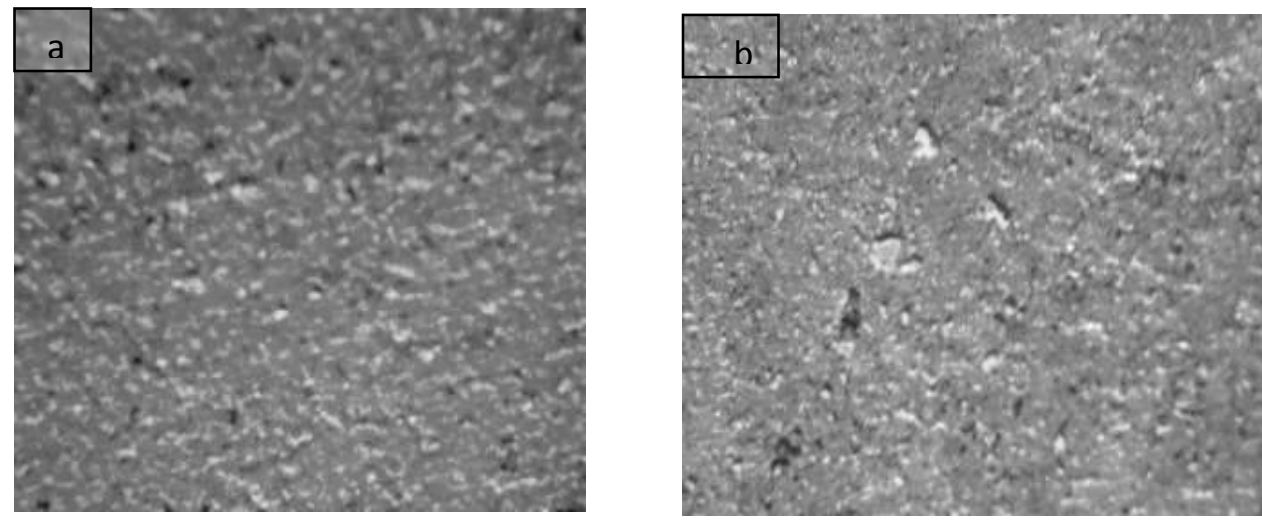

Plate 3: Aqueous Corrosion of Car Model 2005 surface specimen a- after 4 weeks b- after 10 weeks

Magnification: X40

\section{Conclusions:}

1- In Mosul City, and during the period of study 2009-2010, atmospheric corrosion of car body steels studied are classified as low rate corrosion, due to dry weather conditions, low humidity\%, and small rain fall and wet duration.

2- Corrosion rate values of the body car models studied are affected by micro-alloying elements, previous thermo-mechanical steel processing, and mechanical properties of sheet steel.

3- Corrosion rate under aqueous condition are classified as low rates due to good water quality index of Mosul fresh water, low langelier saturation index, and ideal corrosion index.

\section{Reference:}

1- Baboian R., "Corrosion Tests and Standards, Application and Interpretation", $2^{\text {nd }}$ Ed., ASTM, USA, 2003, pp. 677-680.

2- Eman J., "Study and Characterization of Localization and Failure Behavior of Ultra High Strength Steel ", Msc. Thesis Submitted to Lulea University of Technology, Sweden, 2007, p19.

3- Avallone A., "Marks Standard Handbook for Mechanical Engineers ", McGraw Hill, $10^{\text {th }}$ Ed., 1996, pp. 6-69.

4- Hamzah E., "Corrosion Behavior of Low Carbon Steel Sheets for Car Bodies ", Journal Mekanikal, Malaysia No. 19, 2005, pp. 57-70.

5- ASM International, " Corrosion: Fundementals, Testing, and Protection ", Vol. 13a, 2003. pp. $57-70$.

6- Von Backmann W. "Cathodic Corrosion Protection", Gulf Prevention Publish, $3^{\text {rd }}$ Ed., USA, 1997, pp.139.

7- Llewellyn D.," Steels, Metallurgy, and Application ", Butterworth - Heinmann, $3^{\text {rd }}$ Ed., 2004, pp. $115-120$.

8- Langer T., Buchta W., "High Strength, Light Weight Car Bodies for High Speed Rail Vehicles", Final Report of High Speed Rail IDEA, Project 32, 2003, Sweden. 
9- Diaz I., Cano H., Chico B., de la Fucito D., Morcillo M., " Some Clarificatio Regarding Literature on Atmospheric Corrosion of Weathering Steels ", International Journal of Corrosion, Volume 2012, Article ID812192, 9 pages.

10- Garcia J., Hallen J., " Microstructural Aspect of Brittleness Phenomenon in Steel Induced by Mill Annealing", Journal Revista Mexicana De Fisica, 555(1), 2009, pp.68-71.

11- Katundi D., Bayraktar E., "Corrosion Behavior of the Welded Steel Sheets Used in Automotive Industry", Journal of Achievements in Materials and Manufacturing Engineering, Vol.38, Issue 2, 2010.

$$
\begin{aligned}
& \text { 12- معلومات ميدانية اخذت من محطة الانو اء الجوية في الرشيدية ومحطة ماء الرشيدية ومن تقرير الاحصاءات } \\
& \text { البيئية للعراق إن إنية } \\
& \text { 13- إبر اهيم د.صبحي، عبداله ياسر-، " نأثثر نسبة الكاربون على مقاومة التآكل للصلب الكاربوني في الاوساط }
\end{aligned}
$$

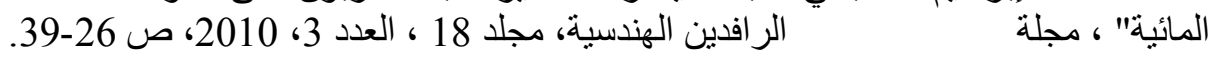

14- Ramerz J., Genesca J., "Evaluation of Atmospheric Corrosion in Orizaba, Mexico", Atmosfera 25(4), pp. 397-406, 2012.

15- Nagano H .,Yamashita M. ,"Atmospheric Corrosion Process For Weathering Steel" International Corrosion Engineering Conference, Seonl,2007,RAC-0-10.

16- Cstafio J., Botero C., Restrepo A., Agudelo E., " Atmospheric Corrosion of Carbon Steel in Columbia ", Journal of Corrosion Science, Vol.52, pp. 216- 223, 2010.

17- Han W., Yu G., Wang Z., "Characterization of Initial Atmospheric Corrosion Carbon Steel by Field Exposure and Laboratory Simulation", Journal of Corrosion Science, Vol. 49, pp. 2920-2935, 2007.

18- Chen Y., Tzing H., Wei L., " Mechanical Properties and Corrosion Resistance of Low Alloy Steels in Atmospheric Conditions Containing Chloride" Journal of Material Science and Engineering, A398, pp. 47 - 59, 2005.

19- Lakshmana L., Chandhari G., Nooth S., " Mechanical and Corrosion Behavior of Plain Carbon Dual Steels", Journal of Material and Design, Vol. 32, pp. 433 - 440, 2011.

20- Moncmanova A. , "Environmental Deterioration of Materails", WIT Press 2007, pp. 9095.

21- Sastri V.,"Corrosion Prevention and Protection", John Willey \& Sons Ltd., pp. 204-206, 2007.

22-Fang H., Young D., Nasic S., "Corrosion of Mild Steel in the Presence of Elemental Sulfur" NACE Corrosion Conference, Paper 08657, 2008.

23- Paul S., "Modeling to Study the Effect of Environmental Parameter Corrosion of Mild Steel in Seawater Using Neutral Network", Intern. Scholary Research Network, Vol.2012, Article ID487351, 6 pages.

24- Alobaidy A., Moulood B., Kadhem A., "Evaluating Raw and Treated Water Quality of Tigris River within Baghdad by Index Analysis “, J. Water Resource and Protection, Vol.2, pp. 629-635, 2010. 